\title{
Timing of larval release by three barnacles from the NW Iberian Peninsula
}

\author{
G. Macho ${ }^{1,2}$, J. Molares $^{1}$, E. Vázquez ${ }^{2, *}$ \\ ${ }^{1}$ Centro de Investigacións Mariñas, Xunta de Galicia, 36620 Vilanova de Arousa, Spain \\ ${ }^{2}$ Dpto Ecoloxía e Bioloxía Animal, Facultade de Ciencias, Universidade de Vigo, 36310 Vigo, Spain
}

\begin{abstract}
The timing of larval release and the cues that control these rhythms (tidal, diurnal, or lunar cycles) were studied over a 2 mo period in the cirripeds Pollicipes pollicipes, Balanus spp. and Chthamalus spp., occurring on an exposed rocky shore in NW Spain. All of them showed rhythms of larval release, but the rhythms were different in each species. Chthamalus spp., which principally inhabit the upper intertidal zone, released their larvae mainly during diurnal high tides at the time of new and full moons. Larval release was greater during the afternoon than during the morning, because the amplitude of afternoon high tides was significantly higher than that of morning high tides. P. pollicipes larvae were released at morning high tide during waning moon and, to a lesser extent, during full moon. Nauplii of Balanus spp. were released during new and waning moons; almost no release occurred during full moon, and no larvae were found during the waxing moon, mainly during diurnal high tides. P. pollicipes and Balanus spp. usually began to release larvae after sunrise, which may be the factor inducing synchrony. In contrast, Chthamalus spp. released larvae at any time of day, but always coinciding with high tide, indicating that seawater may be the cue that triggers larval release in this species. Although larval release should occur during safe periods (e.g. night-time) in species such as those under study, with small unprotected colored larvae that are visible to predators, almost no larvae of any of the 3 cirripeds were found at night. Cirriped Nauplius I larvae respond positively to light, allowing larvae to travel upwards in the water column, away from congeners that could incidentally ingest their own larvae, and are transported offshore away from predators, which are more abundant close to the shore. At night this photopositive behavior does not take place, and thus the synchrony in the emission of larvae during daytime induces larval aggregation, which may increase larval survival because of the swamp effect over predators.
\end{abstract}

KEY WORDS: Larval release $\cdot$ Rhythms · Tides · Diurnal $\cdot$ Lunar $\cdot$ Cues $\cdot$ Barnacles $\cdot$ Nauplius Resale or republication not permitted without written consent of the publisher

\section{INTRODUCTION}

Reproductive synchrony is prevalent among marine invertebrates, as has been demonstrated in sponges (e.g. Hoppe \& Reichert 1987, Amano 1988, Mariani et al. 2001), corals (e.g. Babcock et al. 1986), polychaetes, mollusks (e.g. Korringa 1947), decapod crustaceans (e.g. Forward 1987), echinoderms (e.g. Pearse 1975, Lessios 1991) and ascidians (Olson 1983). The selective factors that synchronize reproduction differ among marine animals (revised by Giese \& Pearse 1974 and Giese \& Kanatani 1987), although the majority reproduce by environmental cycles generated by move- ments of the earth (circadian rhythms, approximately $24 \mathrm{~h}$ ) and moon (circatidal rhythms, usually about $12.4 \mathrm{~h}$, but sometimes about $22.48 \mathrm{~h}$, and circasemilunar rhythms, about $14.8 \mathrm{~d}$ ) that occur with predictable regularity.

In marine intertidal species, reproduction is timed so that larvae are released into the water when conditions are optimal for transportation and survival (Morgan 1995). Synchronous reproduction may minimize predation on larvae because they will be released (1) when predators are absent or not feeding ('the avoidance hypothesis'), as has been demonstrated in crabs (review in Morgan \& Christy 1997), or (2) when 
they are so abundant that predators are sated, thereby increasing the probability of survival of each larva ('the swamping hypothesis') (Ims 1990). Moreover, the rhythmicity of larval release strongly affects the transport and dispersal of larvae of coastal and estuarine decapods (Christy \& Stancyck 1982); thus, the timing will affect not only larval mortality, but also recruitment of larvae to populations (Queiroga et al. 1994).

Larval release in decapod crustaceans has been widely investigated (see Christy 1982, Forward 1987, Morgan \& Christy 1995), and the timing of larval release has usually been found to be related to the tide (occurring around high tide), time of the day (mainly occurring in the first half of the night) and lunar phase (mainly at new and full moon); nevertheless, exceptions to these general patterns have been observed (Morgan 1996, Morgan \& Christy 1997). However, while settlement in cirriped crustaceans has been widely studied worldwide (e.g. Barnes \& Powell 1950, Hawkins \& Hartnoll 1982, Kendall et al. 1982, 1985, Hills \& Thomason 1996, O'Riordan et al. 1999, Cruz 2000, Power et al. 2001), larval release has received less attention (but see H. Barnes 1957, 1962, Cawthorne \& Davenport 1980, M. Barnes 1989, Starr et al. 1991, Walker 1992).

Several methods have been used to determine the timing of larval release by marine invertebrates in natural populations. Larval release may be observed directly in the field; this has been carried out for semiterrestrial crabs that walk to the water to release larvae (e.g. Saigusa 1982) and for subtidal ascidians (e.g. Olson \& McPherson 1987). However, direct observations are not possible for marine invertebrates that hatch small larvae at night in turbid or turbulent waters. Under these conditions, the timing of larval release can be determined by caging egg-bearing females and observing when they release their egg masses (e.g. Gove \& Paula 2000). The most common methods applied in the field include periodically collecting young larvae from the plankton (e.g. Paula 1989, Queiroga et al. 1994, Drake et al. 1998) or sampling females from natural populations to monitor egg development (e.g. De Vries \& Forward 1989, Gove \& Paula 2000), although these methods are somewhat imprecise.

Pollicipes pollicipes, Chthamalus montagui and Balanus perforatus (Crustacea: Cirripedia: Thoracica) are common inhabitants of the exposed and semi-exposed intertidal rocky shores of Galicia (Atlantic coast of the Iberian Peninsula). The barnacle P. pollicipes is present in the low- and mid-intertidal zones of this rocky shore. $B$. perforatus is very abundant in the low-intertidal zones and the first few meters of subtidal levels, whereas $C$. montagui inhabits the high- and mid-intertidal zones. Another species of this latter genus, C. stellatus, is also present on the Galician coast, although it is very sparse in the exposed intertidal zone and more abundant in sheltered localities. This distribution pattern of both species of Chthamalus is opposite to that described for the British coast, where C. stellatus occupies exposed rocky shores and $C$. montagui sheltered localities (Southward 1976). In addition to $B$. perforatus, the species $B$. crenatus has also been described from the Galician coast, although it is very rare and inhabits the subtidal zone.

The aim of the current study was to determine the predictability of rhythms of larval release in exposed rocky shore barnacles and to examine the possible cues that control the rhythms: diurnal, tidal and lunar cycles.

\section{MATERIALS AND METHODS}

Collection and maintenance. Sampling was carried out at Cabo Couso $\left(42^{\circ} 15.0^{\prime} \mathrm{N}, 8^{\circ} 52.30^{\prime} \mathrm{W}\right)$, a very exposed rocky shore in Galicia (NW Iberian Peninsula) (Fig. 1A). This coast is characterized by semidiurnal mesotides, with a tidal range of almost $4 \mathrm{~m}$. The

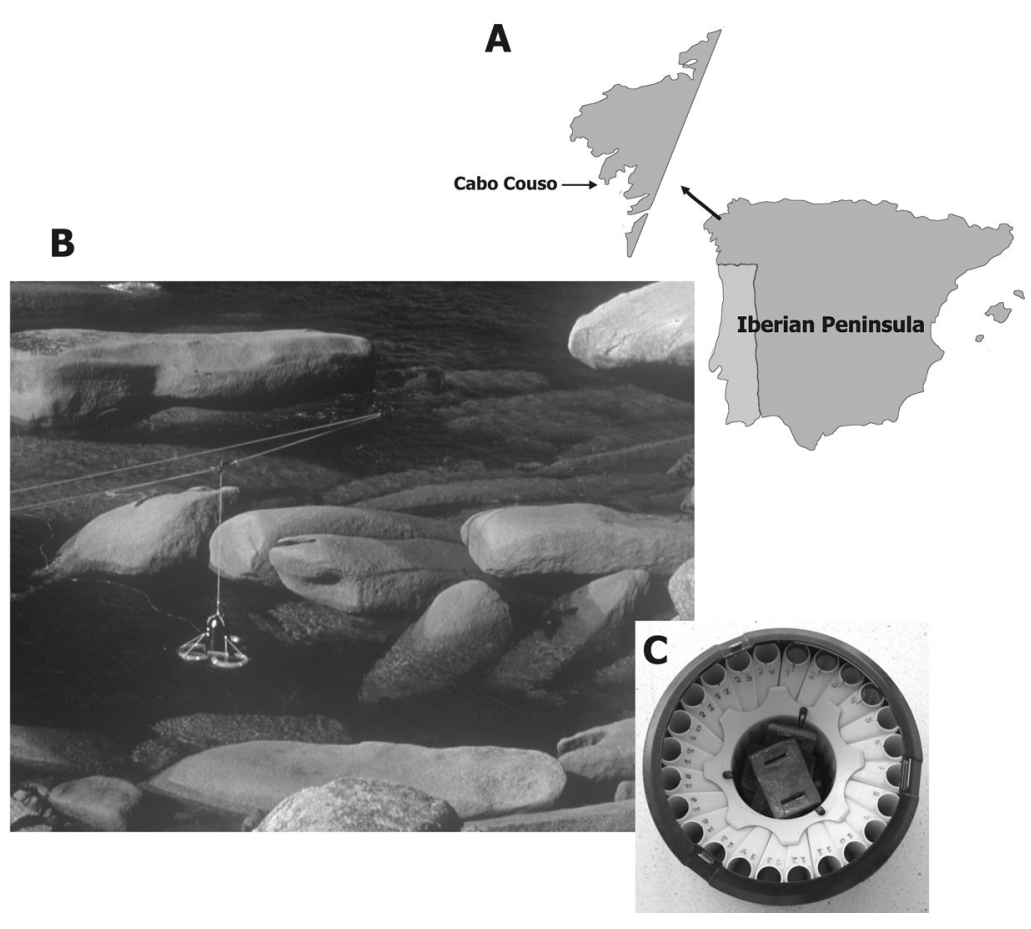

Fig. 1. (A) Map showing the study site in Galicia (NW Iberian Peninsula). (B) Picture showing how the peristaltic pump was set up in the intertidal zone of the exposed rocky shore on an unusually calm day. (C) Filters on which larvae were retained 
sampling site was located $5 \mathrm{~m}$ from the water's edge (Fig. 1B), where the depth during low spring tides was $0.5 \mathrm{~m}$. The sampling site has a very irregular topography, with many rocky boulders where waves break, generating strong turbulence and water currents flowing in and out through channels among the boulders (Fig. 1B).

Samples were collected over a 2 mo period (August and September 2001), when cirriped larvae were abundant in the plankton (G. Macho et al. unpubl. data) and mature adults were found on the rocky shores (mean of adults with ovisacs for both months was $15 \%$ for Balanus perforatus, $50 \%$ for Chthamalus montagui and $70 \%$ for Pollicipes pollicipes).

Larvae were sampled on 3 consecutive days in each lunar phase, beginning at 20:00 $\mathrm{h}$ and finishing at 20:00 h 3 d later. Larvae were collected using a modified SIGMA 900 LITE peristaltic automatic pump fitted with 24 filters (Fig. 1C). The pump floated on the surface of the water, and water was collected through a hose from a depth of $0.5 \mathrm{~m}$. Seawater was pumped for 10 min every $2 \mathrm{~h}$. The hose was purged completely between samplings. The pumping outflow was calibrated before the start of the experiment so that each $10 \mathrm{~min}$ of pumping corresponded to filtering of $40 \mathrm{l}$ of water. This volume was the maximum filtration capacity of the pump. However, because of technical problems, a few samples did not comprise $40 \mathrm{l}$ (min.: 33 l, max.: 42 1), and, in such cases, the larval abundance was adjusted to $40 \mathrm{l}$. The outflow was filtered through a $100 \mu \mathrm{m}$ mesh from which zooplankton was collected.

The fact that pumping was carried out in very shallow water may have led to underestimation of the larval abundance if the larvae stayed close to the bottom. However, the water column at the study site is well mixed due to the turbulence caused by strong waves. Moreover, we did not find any correlation between the number of larvae collected and the height of the waves or the wind speed. We thus assumed that densities of Nauplius I and II stages collected by the pump reflected the magnitude of larval release.

Larvae were identified and categorized by stages. For larval classification the following descriptions were used: Norris \& Crisp (1953) for Balanus perforatus, Pyefinch (1948) for B. crenatus, Burrows et al. (1999) for Chthamalus montagui and C. stellatus, and Bassindale (1936) and Pyefinch (1948) for Verruca stroemia. In estimating larval release we counted Nauplius I and II stages. We included Nauplius II because the first stage only lasts for a few hours and some larvae may metamorphose to the Nauplius II stage between being collected and being transported to the laboratory, where they were fixed in $4 \%$ buffered formalin in seawater.
Data analysis. Rough seas sometimes prevented sampling, usually during new and waxing lunar phases in August (Table 1). Hence, to standardize the number of samples for the study of lunar patterns of larval release, we analyzed data corresponding to 1 complete $24 \mathrm{~h}$ cycle during the central day of each lunar phase in September. A G-test for goodness-of-fit for $>2$ classes (Sokal \& Rohlf 1995) was applied to the percentage of Nauplius I/II larvae found at each lunar phase. Larval abundance at low and high tide during the daytime or during the night was also analyzed by a $G$-test for goodness-of-fit for $>2$ classes.

Table 1. Sampling dates in 2001 for each lunar phase, and time of the day when samples were lost in each sampling day. Sampling began at 20:00 $\mathrm{h}$ and finished at 20:00 h $3 \mathrm{~d}$ later. -: no samples were $\operatorname{lost}_{i}{ }^{*}$ : all samples were lost

\begin{tabular}{|c|c|}
\hline $\begin{array}{l}\text { Sampling date } \\
\text { (d-mo) }\end{array}$ & $\begin{array}{c}\text { Time of day (h) } \\
\text { when samples were lost }\end{array}$ \\
\hline \multicolumn{2}{|l|}{ Full moon } \\
\hline $02-08$ & $20: 00,22: 00$ \\
\hline 03-08 & From $00: 00$ to $18: 00$ \\
\hline 04-08 & - \\
\hline $05-08$ & - \\
\hline \multicolumn{2}{|l|}{ Waning moon } \\
\hline $10-08$ & $20: 00,22: 00$ \\
\hline $11-08$ & From 00:00 to $08: 00$ \\
\hline $12-08$ & - \\
\hline $13-08$ & - \\
\hline \multicolumn{2}{|l|}{ New moon } \\
\hline $17-08$ & $20: 00,22: 00$ \\
\hline $18-08$ & $*$ \\
\hline $19-04$ & * \\
\hline $20-08$ & * \\
\hline \multicolumn{2}{|l|}{ Waxing moon } \\
\hline $23-08$ & $20: 00,22: 00$ \\
\hline $24-08$ & From $00: 00$ to $10: 00,20: 00$ and $22: 00$ \\
\hline $25-08$ & From 00:00 to $12: 00$ and 22:00 \\
\hline $26-08$ & Collected only at 10:00 \\
\hline \multicolumn{2}{|l|}{ Full moon } \\
\hline $31-08$ & - \\
\hline 01-09 & - \\
\hline 02-09 & - \\
\hline 03-09 & - \\
\hline \multicolumn{2}{|l|}{ Waning moon } \\
\hline $08-09$ & - \\
\hline 09-09 & - \\
\hline $10-09$ & - \\
\hline 11-09 & - \\
\hline \multicolumn{2}{|l|}{ New moon } \\
\hline $15-09$ & - \\
\hline $16-09$ & $22: 00$ \\
\hline $17-09$ & Collected only at 10:00 \\
\hline 18-09 & From $00: 00$ to $08: 00,16: 00$ to $20: 00$ \\
\hline \multicolumn{2}{|l|}{ Waxing moon } \\
\hline $22-09$ & $20: 00,22: 00$ \\
\hline $23-09$ & 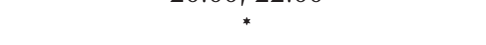 \\
\hline 24-09 & From 00:00 to $12: 00$ \\
\hline $25-09$ & $20: 00$ \\
\hline
\end{tabular}




\section{RESULTS}

\section{Larval stage composition}

A total of 5254 cirriped crustacean larvae were collected during the study. The larvae were categorized into 2 species (Pollicipes pollicipes and Verruca stroemia), 2 genera (Balanus spp. and Chthamalus spp.), and 7 larval stages (Nauplii I to VI and cypris). Nauplius I and II larvae predominated and represented $97.24 \%$ of all individuals collected. Only 18 $(0.34 \%)$ later nauplius larval stages (Nauplii III to VI) and $127(2.41 \%)$ cypris larvae were identified. Chthamalus spp. were the best represented, with a total of 4611 (87.75\%) Nauplii I and II and 104 (1.98\%) cypris larvae. The percentages of early nauplius larvae of Balanus spp. and P. pollicipes were 4.49 and $4.32 \%$, respectively. Only $9 P$. pollicipes cyprids and 13 Balanus spp. were found. Larvae of $V$. stroemia represented just $0.61 \%$ of the total number of larvae captured, and, because of its low abundance and subtidal habitat, this species was not included in the analysis.

\section{Lunar patterns of larval release}

Timing of larval release relative to the lunar cycle did not occur randomly in the 3 species but rather was precisely timed, coinciding with lunar phases. In September, larvae of Pollicipes pollicipes were mainly released during waxing and full moons (Fig. 2A) (Gtest $p<0.005$ ), whereas release of Chthamalus spp. larvae occurred during full and new moons, corresponding to the spring tides (G-test $\mathrm{p}<0.001)$ (Fig. 2B). Nauplius I to II larvae of Balanus spp. were more abundant during new and waning moons $(G$-test $\mathrm{p}<0.001)$ and were sparse or absent during full and waxing moons, respectively (Fig. 2C).

\section{Time of the day and tidal patterns of larval release}

Larval release did not occur randomly throughout the day and the tidal cycle. Most nauplii of all 3 species were released when high tide occurred during the day (G-test $\mathrm{p}<0.001$ for all 3 species) (Fig. 3A). Several peaks that followed a fairly consistent pattern occurred, although this pattern differed in each species.

Larval release of Pollicipes pollicipes mainly occurred during high tide, especially morning high tides (G-test $\mathrm{p}<0.001$, Figs. 3B \& 4). Very few larvae were observed during the afternoon high tide and after sunset.

There was a clear tidal pattern of larval release in Chthamalus spp., with a strong peak during diurnal

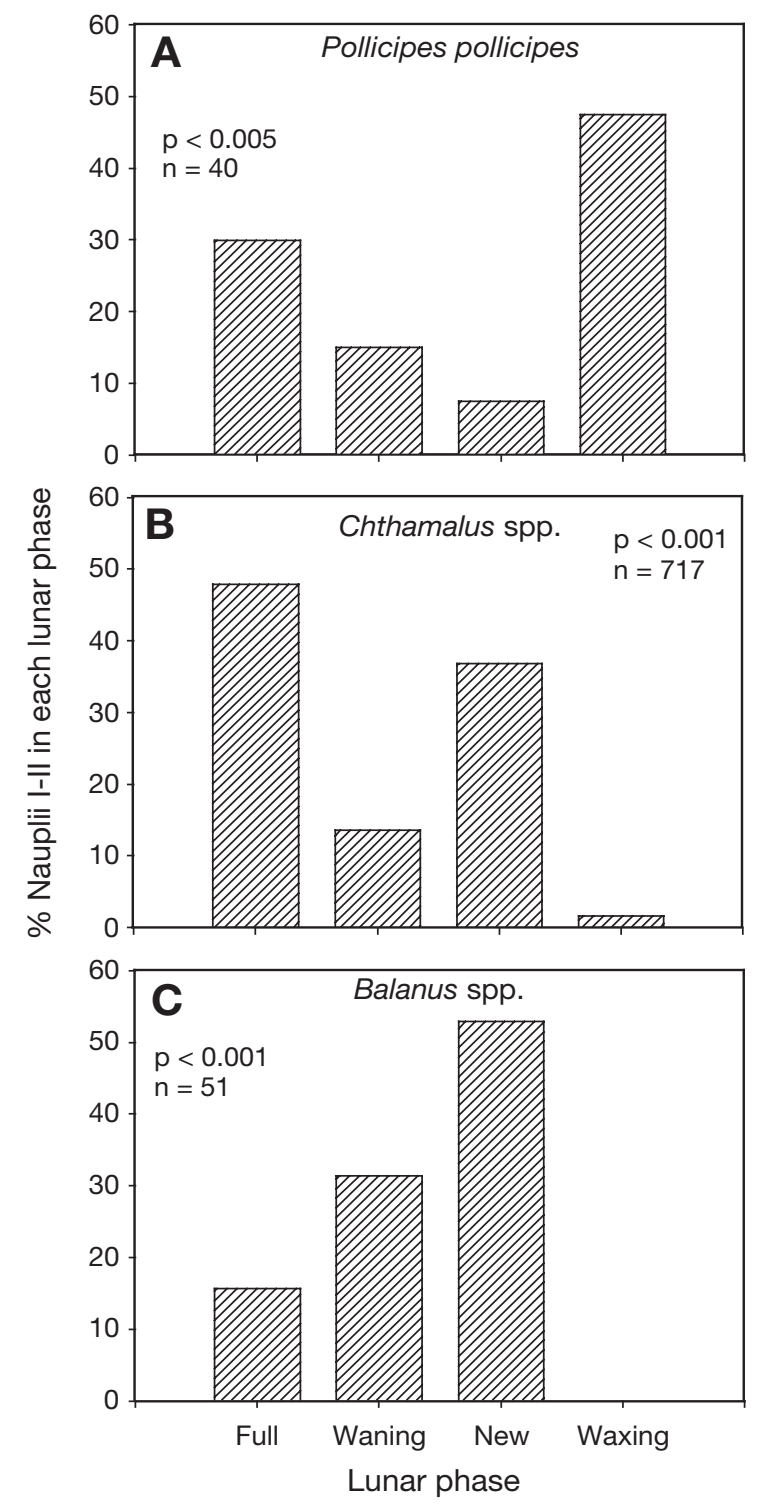

Fig. 2. Percentage of early nauplius stage larvae found over a complete $24 \mathrm{~h}$ cycle in each lunar phase of the month of September: (A) Pollicipes pollicipes, (B) Chthamalus spp. and (C) Balanus spp. Note that no Balanus spp. larvae were found during a waxing moon

high tides (G-test $\mathrm{p}<0.001$, Fig. 3). Few larvae were collected during low spring tides, although some were found during the entire tidal cycle, even during low tides of lower amplitude (Fig. 5). Almost no larvae were collected during the night (Figs. 3A \& 5).

Very few larvae of Balanus spp. were collected; thus, the results are inconclusive. Significant larval release occurred at sunrise (Fig. 6), followed by less intense release throughout the entire tidal cycle until sunset, when it stopped (only 10 larvae were found during the night). Most larvae were released during high tide (G-test $\mathrm{p}<0.001$, Fig. 3). 


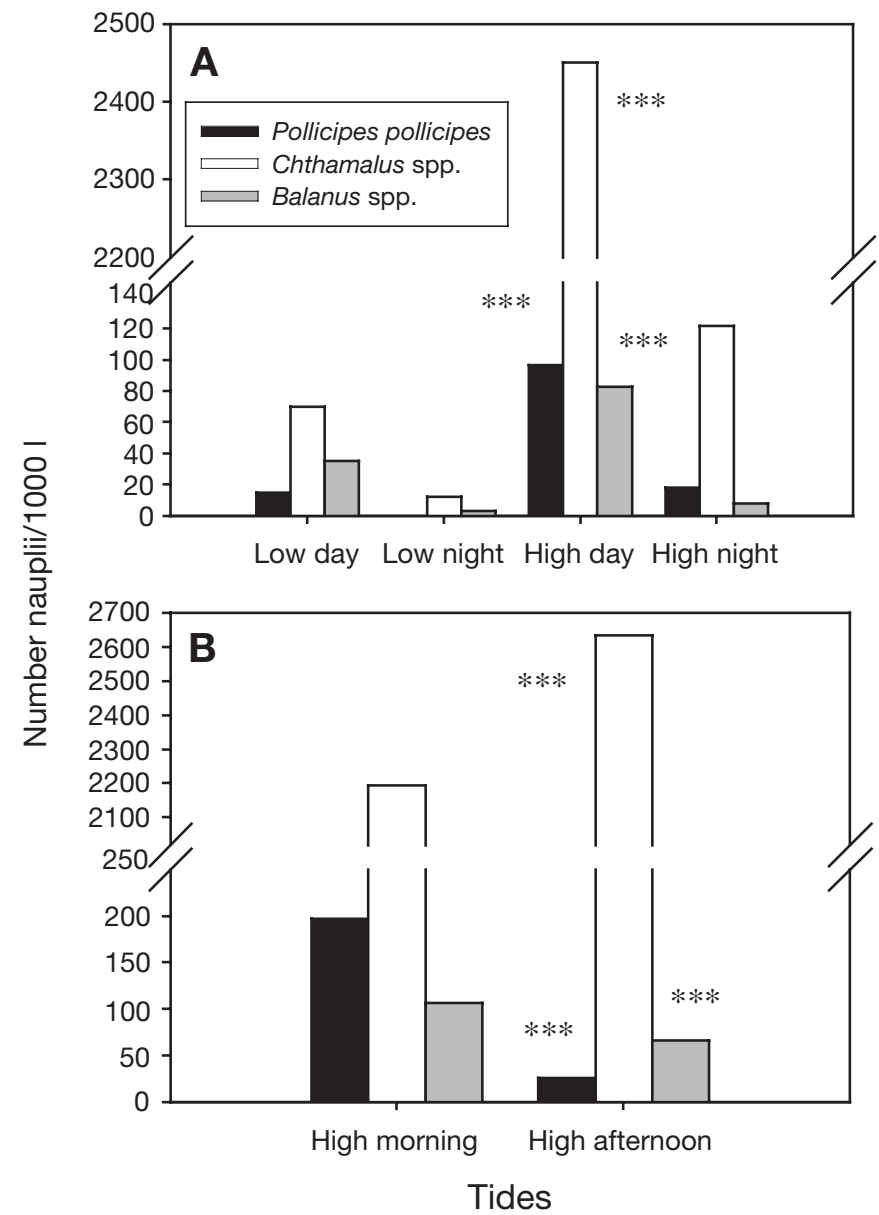

Fig. 3. Number of early nauplius stage larvae of Pollicipes pollicipes, Chthamalus spp. and Balanus spp. filtered from $1000 \mathrm{l}$ of seawater in each combination of: (A) low and high tide and light/dark period and (B) high tide in the morning (from sunrise till midday, i.e. at approx. 14:30 h) and in the afternoon (from midday till sunset) (G-test, $* * * \mathrm{p}<0.001$ for 3 species)

\section{DISCUSSION}

Hatching should occur when phase relationships between the tides, the light/dark cycle and tidal amplitude are most favorable for larval survival (Kellmeyer \& Salmon 2001). The barnacles Chthamalus spp., Pollicipes pollicipes and Balanus spp. showed rhythms of larval release that differed in each species. Nauplii of Chthamalus spp. were mainly released during diurnal high spring tides (new and full moon) or at morning high tides during a waning moon. This species requires high tides to release its larvae, because it mainly occurs in the upper intertidal zone, and adult populations spend most of their time out of the water. Furthermore, larval release was greater during the afternoon than during the morning, because the amplitude of afternoon high tides was significantly higher (Mann-Whitney $U$-test, $p=0.007$ ) than that of the morning high tides. Several synchronous hatching periods during the reproductive season of Chthamalus montagui and C. stellatus have already been suggested (Kendall \& Bedford 1987, Burrows et al. 1992), although the triggering factor was not specified.

Pollicipes pollicipes larvae were released at morning high tide during the waning moon and, to a lesser extent, during full moon. Until now the only available information about hatching of this species was inferred from calculations of the percentage of embryos in late developmental stages, which indicated asynchronous larval release in the southwest of Portugal (Cruz 2000). Nauplii of Balanus spp. were released during new and waning moons; almost no release occurred during full moon, and no larvae were found during the waxing moon. Release occurred mainly during diurnal high tide, although larvae were also collected during low tide, probably because of the location in the lower level of the intertidal zone, which is only exposed for a short period during any tide.

Crab larvae that hatch during the largest amplitude lunar or semi-lunar tides are transported at maximum velocities, by ebb currents, from shallow to deeper waters, where the risk of predation is reduced (Christy 1982, Christy \& Stancyk 1982, Morgan 1987, 1990). The species under study showed a different behavior pattern: Chthamalus spp. released its larvae during spring tides; thus, despite being released during the day, larvae would rapidly be washed away from the coast. In fact, the most abundant larval stages of the 3 species at the sampling site were Nauplii I and II, and only $0.34 \%$ were later nauplius stages (III to VI), indicating that larvae were washed away from the coast after release. The larvae may thus be dispersed very quickly and avoid predation, since in coastal environments the density of planktivorous fishes decreases with increasing distance from the shore (review Morgan 1986). Similar behavior was observed in the larvae of the New Zealand cirriped Chamaesipho brunnea; this species releases its larvae during spring tides and storms, whereas larvae do not hatch during neap tides and calm weather, despite being ready (Luckens 1970).

Pollicipes pollicipes and Balanus spp. usually began to release larvae after sunrise. According to Paula (1989, 1993) and Saigusa \& Kawagoye (1997), sunset and sunrise are the only perceptible phenomena that could induce synchrony. In contrast, Chthamalus spp. released larvae at any time of the day, but always coinciding with high tide, indicating that seawater may be the cue that triggers larval release in this genus. Christy (1986) suggested that larval release would not need to be synchronized with high spring tides in crabs that inhabit intertidal exposed shores, because they would not require higher amplitude tidal currents to disperse their larvae. This author further suggested 

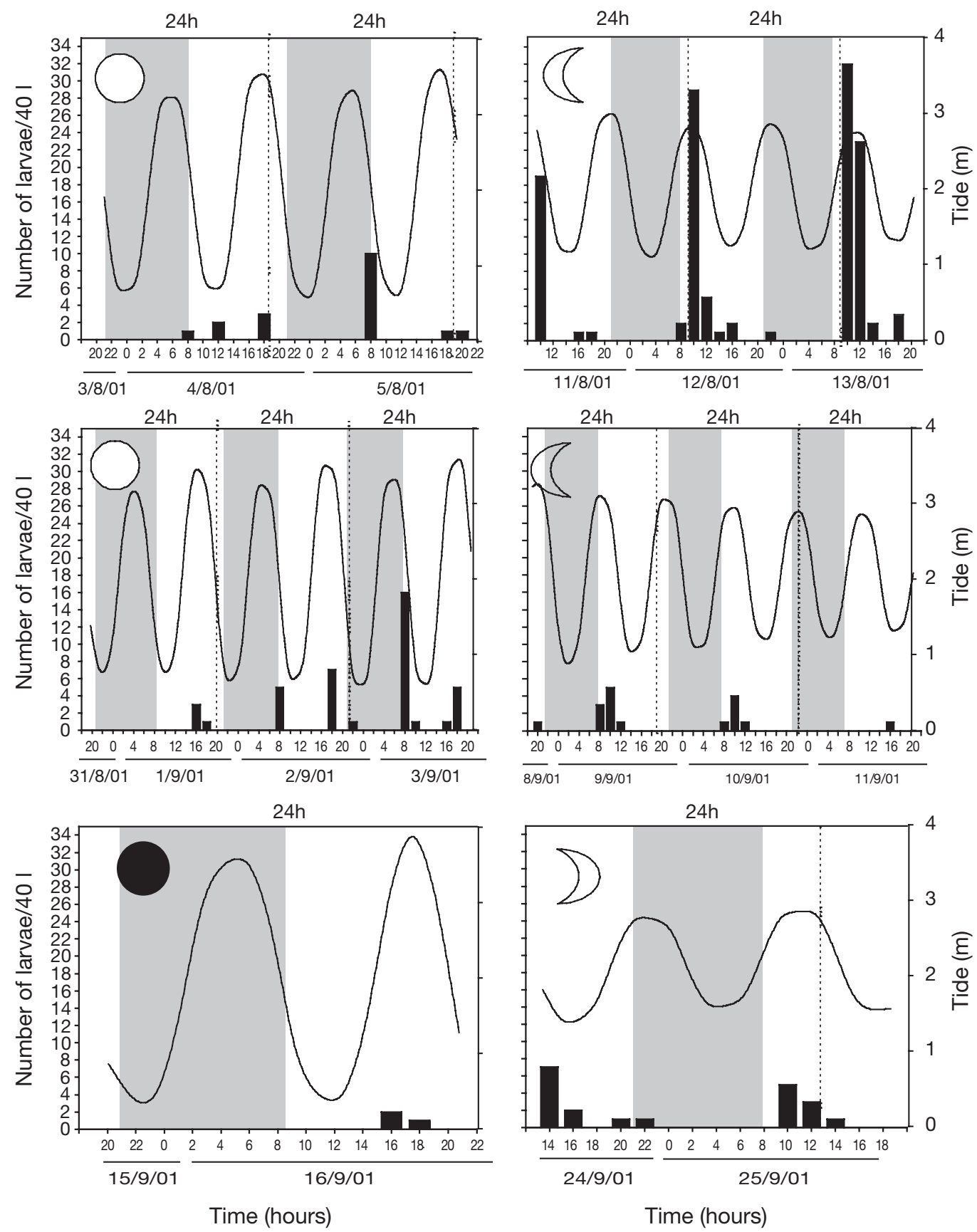

Fig. 4. Pollicipes pollicipes. Number of early nauplius stage larvae filtered from $40 \mathrm{l}$ of seawater in each lunar phase during $24 \mathrm{~h}$ cycles (dates given as $\mathrm{d} / \mathrm{mo} / \mathrm{yr}$ ). The shaded area represents night. The amplitude of the tides is also shown

that the adaptive value of larval release in maximumamplitude tides is restricted to estuarine zones. This may also be true for the other 2 species that inhabit the middle and lower intertidal zone, but not for species that inhabit the upper intertidal zone.

Despite the fact that larval release should occur during safe periods such as night-time and during higher amplitude and high tides (Morgan 1995), when sur- vival of larvae is enhanced, almost no larvae (only 21 out of 5100 early nauplii) of the 3 cirripeds under study were found at night, independent of the tide or the moon. Cirriped Nauplius I larvae respond positively to light, allowing larvae to travel upwards in the water column, away from congeners that could incidentally ingest their own larvae - as has been demonstrated for Semibalanus cariosus (Navarrete \& Wieters 

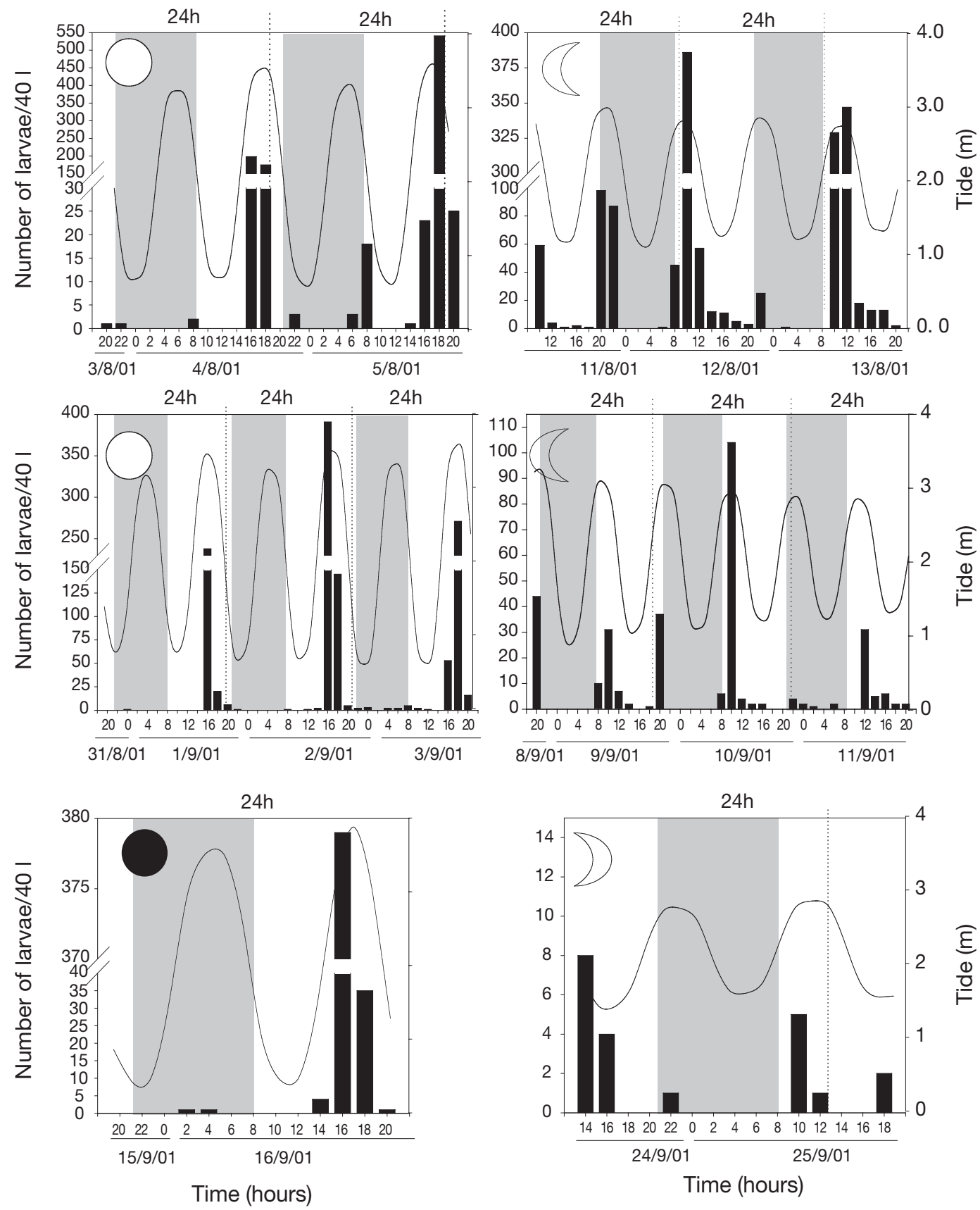

Fig. 5. Chthamalus spp. Number of early nauplius stage larvae filtered from $40 \mathrm{l}$ of seawater in each lunar phase during $24 \mathrm{~h}$ cycles (dates given as $\mathrm{d} / \mathrm{mo} / \mathrm{yr}$ ). The shaded area represents night. The amplitude of the tides is also shown. Note the different scales on the $y$-axis

2000) — and also allowing them to be washed offshore. In the absence of light at night this photopositive behavior would obviously not take place. We do not believe that this conclusion is a sampling artifact due to pumping water from a depth of $0.5 \mathrm{~m}$. If this were so, at low spring tides when the hose was pumping very close to the bottom ( $1 \mathrm{~m}$ depth), larvae would be collected at night, and this never happened.
Most crab species release their larvae during the night, and those that hatch during the day have inconspicuously colored larvae that are not visible to predators (Morgan \& Christy 1997) and that are often large and well defended. Nauplius I of Pollicipes pollicipes, Chthamalus spp. and Balanus spp. are orange (due to the presence of the yolk sac), do not have spines for defense and are small (204 to $279 \mu \mathrm{m})$, and would 

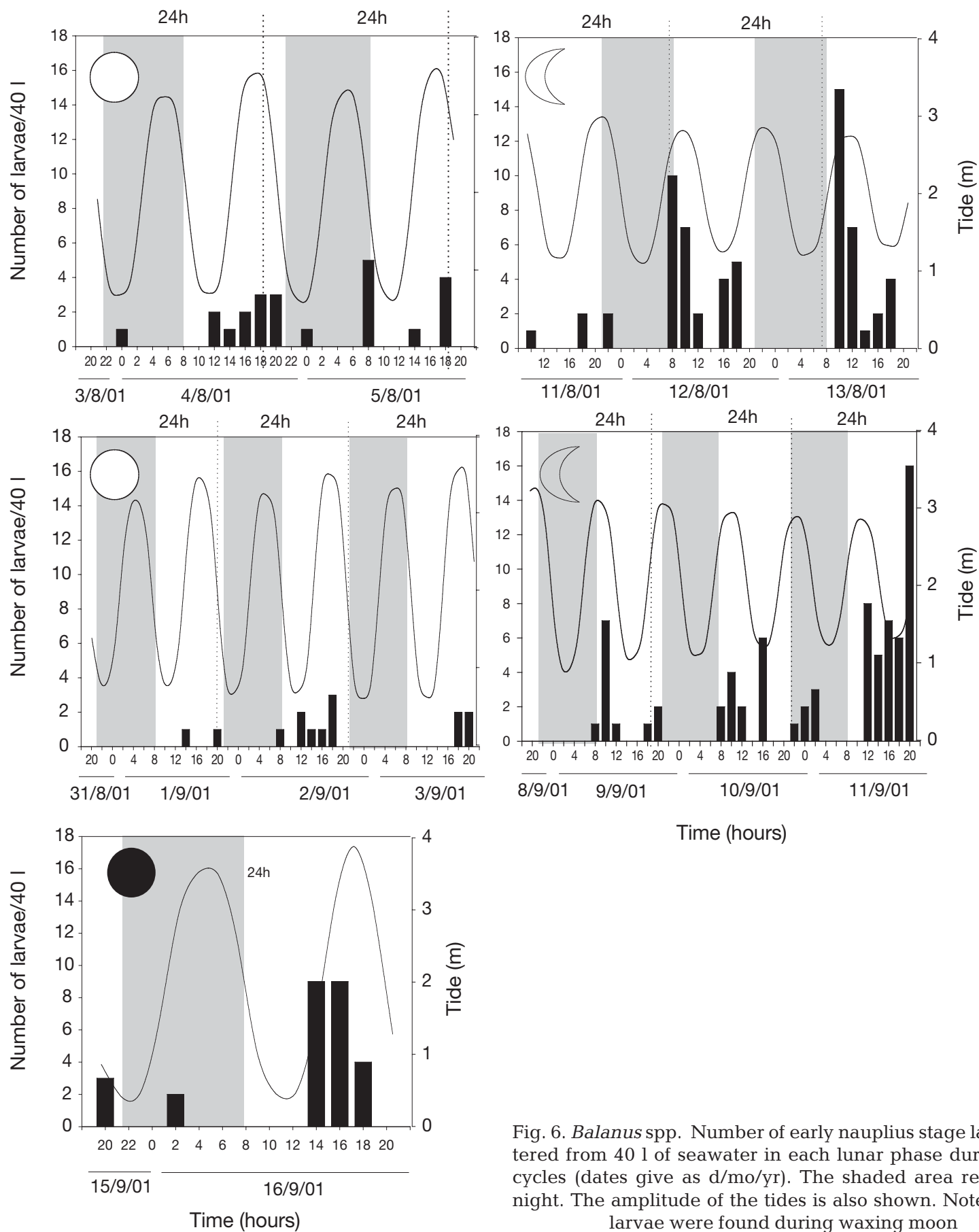

Time (hours)

Fig. 6. Balanus spp. Number of early nauplius stage larvae filtered from $40 \mathrm{l}$ of seawater in each lunar phase during $24 \mathrm{~h}$ cycles (dates give as $\mathrm{d} / \mathrm{mo} / \mathrm{yr}$ ). The shaded area represents night. The amplitude of the tides is also shown. Note that no larvae were found during waxing moon

therefore be very vulnerable to predators (Morgan \& Christy 1997). Despite the fact that planktivorous fish feed during the day, thus creating greater pressure for night hatching, larvae should be released during the daytime because of their photopositive behavior, and therefore the synchrony in the emission of larvae by the releasing population, which induces larval aggregation, would increase larval survival because of the swamp effect over predators (Lobel 1978). This appears to be particularly true for Chthamalus spp.

Complex shifts in the timing of tides relative to light/dark and lunar cycles may cause considerable intraspecific variation in larval release. A clear understanding of the relationships among environmental cycles is necessary in studying the plasticity in the timing of larval release. 
Acknowledgements. The study was funded by 'Secretaría Xeral de Investigación e Desenvolvemento' of the 'Xunta de Galicia' (PGIDT-CIMA-99/5). We acknowledge a fellowship to G.M. from the 'Xunta de Galicia'. We are grateful to R. Giráldez for his technical assistance in the field and laboratory and to S. Novo for help with the fieldwork. We also appreciate the comments and suggestions made by Dr. F. Peters and 4 anonymous referees.

\section{LITERATURE CITED}

Amano S (1988) Morning release of larvae controlled by the light in an intertidal sponge, Callyspongia ramosa. Biol Bull (Woods Hole) 175:181-184

Babcock RC, Bull GD, Harrison PL, Heyward AJ, Oliver JK, Wallace CC, Willis BL (1986) Synchronous spawning of 105 scleractinian coral species on the Great Barrier Reef. Mar Biol 90:379-394

Barnes H (1957) Processes of restoration and synchronization in marine ecology. The spring diatom increase and the 'spawning' of the common barnacle, Balanus balanoides (L.). Annee Biol 33:67-85

Barnes H (1962) Note on variations in the release of nauplii of Balanus balanoides with special reference to the spring diatom outburst. Crustac Int J Crustac Res 4:118-122

Barnes H, Powell HT (1950) The development, general morphology and subsequent elimination of barnacle populations, Balanus crenatus and B. balanoides, after a heavy initial settlement. J Anim Ecol 19:710-723

Barnes M (1989) Egg production in cirripedes. Oceanogr Mar Biol Annu Rev 27:91-166

Bassindale R (1936) The developmental stages of three English barnacles, Balanus balanoides (Linn.), Chthamalus stellatus (Poli), and Verruca stroemia (O.F. Müller). Proc Zool Soc Lond 106:57-74

Burrows MT, Hawkins SJ, Southward AJ (1992) A comparison of reproduction in co-occurring chthamalid barnacles, Chthamalus stellatus (Poli) and Chthamalus montagui Southward. J Exp Mar Biol Ecol 160:229-249

Burrows MT, Hawkins SJ, Southward AJ (1999) Larval development of the intertidal barnacles Chthamalus stellatus and Chthamalus montagui. J Mar Biol Assoc UK 79: 93-101

Cawthorne DF, Davenport J (1980) The effects of fluctuating temperature, salinity, and aerial exposure upon larval release in Balanus balanoides and Eliminius modestus. J Mar Biol Assoc UK 60:367-377

Christy JH (1982) Adaptative significance of semilunar cycles of larval release in fiddler crabs (genus $U_{C a}$ ): test of an hypothesis. Biol Bull (Woods Hole) 163:251-263

Christy JH (1986) Timing of larval release by intertidal crabs on an exposed shore. Bull Mar Sci 39:176-191

Christy JH, Stancyck SE (1982) Movement of larvae from North Inlet estuary, S.C., with special reference to crab zoaea. In: Kennedy V (ed) Estuarine comparisons. Academic Press, New York, p 498-501

Cruz T (2000) Biologia e ecologia do percebe, Pollicipes pollicipes (Gmelin, 1790), no litoral sudoeste português. $\mathrm{PhD}$ thesis, Universidade de Évora, Évora

De Vries MC, Forward RB Jr (1989) Rhythms in larval release of the sublittoral crab Neopanope sayi and the supralittoral crab Sesarma cinereum (Decapoda: Brachyura). Mar Biol 100:241-248

Drake P, Arias AM, Rodríguez A (1998) Seasonal and tidal abundance patterns of decapod crustacean larvae in a shallow inlet (SW Spain). J Plankton Res 20:585-601
Forward RB Jr (1987) Larval release rhythms of decapod crustaceans: an overview. Bull Mar Sci 41:165-176

Giese AC, Kanatani H (1987) Maturation and spawning. In: Giese AC, Pearse JS, Pearse VB (eds) Reproduction of marine invertebrates, Vol 9. Blackwell Scientific, Palo Alto, CA, p 251-329

Giese AC, Pearse JS (1974) Introduction: general principles. In: Giese AC, Pearse JS (eds) Reproduction of marine invertebrates, Vol 1. Academic Press, New York, p 1-49

Gove D, Paula J (2000) Rhythmicity of larval release in three species of intertidal brachyuran crabs (Crustacea: Brachyura) from Inhaca Island (Mozambique). Mar Biol 136:685-691

Hawkins SJ, Hartnoll RG (1982) Settlement patterns of Semibalanus balanoides (L.) in the Isle of Man (1977-1981). J Exp Mar Biol Ecol 62:271-283

Hills JH, Thomason JC (1996) A multi-scale analysis of settlement density and pattern dynamics of the barnacle Semibalanus balanoides. Mar Ecol Prog Ser 138:103-115

Hoppe WF, Reichert MJM (1987) Predictable annual release of gametes by the coral reef sponge Neofibularia nolitangere (Porifera: Demospongiae). Mar Biol 115:277-285

Ims RA (1990) The ecology and evolution of reproductive synchrony. Am Nat 136:485-498

Kellmeyer K, Salmon M (2001) Hatching rhythms of UCa thayeri Rathbun: timing in semidiurnal and mixed tidal regimes. J Exp Mar Biol Ecol 260:169-183

Kendall MA, Bedford ML (1987) Reproduction and recruitment of the barnacle Chthamalus montagui at Aberystwyth (mid-Wales). Mar Ecol Prog Ser 38:305-308

Kendall MA, Bowman RS, Williamson P, Lewis JR (1982) Settlement patterns, density and stability in the barnacle Balanus balanoides. Neth J Sea Res 16:119-126

Kendall MA, Bowman RS, Williamson P, Lewis JR (1985) Annual variation in the recruitment of Semibalanus balanoides on the North Yorkshire coast 1969-1981. J Mar Biol Assoc UK 65:1009-1030

Korringa P (1947) Relations between the moon and periodicity in the breeding of marine animals. Ecol Monogr 17:349-381

Lessios HA (1991) Presence and absence of monthly reproductive rhythms among eight Caribbean echinoids off the coast of Panama. J Exp Mar Biol Ecol 153:27-47

Lobel PS (1978) Diel, lunar, and seasonal periodicity in the reproductive behaviour of the pomacanthid Centropyge potteri and some reef fishes in Hawaii. Pac Sci 32:193-207

Luckens PA (1970) Breeding, settlement and survival of barnacles at artificially modified shore levels at Leigh, New Zealand. NZ J Mar Freshw Res 4:497-514

Mariani S, Piscitelli MP, Uriz MJ (2001) Temporal and spatial co-occurrence in spawning and larval release of Cliona viridis (Porifera: Hadromerida). J Mar Biol Assoc UK 81: 565-567

Morgan SG (1986) The impact of planktivorous fishes on the life histories of estuarine crabs. PhD thesis, University of Maryland, College Park, MD

Morgan SG (1987) Adaptative significance of hatching rhythms and dispersal patterns of estuarine crab larvae: avoidance of physiological stress by larval export? J Exp Mar Biol Ecol 113:71-78

Morgan SG (1990) Impact of planktivorous fishes on dispersal, hatching, and morphology of estuarine crab larvae. Ecology 71:1639-1652

Morgan SG (1995) The timing of larval release. In: McEdward L (ed) Ecology of marine invertebrate larvae. CRC Press, Boca Raton, FL, p 157-191

Morgan SG (1996) Plasticity in reproductive timing by crabs in adjacent tidal regimes. Mar Ecol Prog Ser 139:105-118 
Morgan SG, Christy JH (1995) Adaptive significance of the timing of larval release by crabs. Am Nat 145:457-479

Morgan SG, Christy JH (1997) Planktivorous fishes as selective agents for reproductive synchrony. J Exp Mar Biol Ecol 209:89-101

Navarrete SA, Wieters EA (2000) Variation in barnacle recruitment over small scales: larval predation by adults and maintenance of community pattern. J Exp Mar Biol Ecol 253:131-148

Norris E, Crisp DJ (1953) The distribution and planktonic stages of the cirripede Balanus perforatus Bruguière. Proc Zool Soc Lond 123:393-409

Olson RR (1983) Ascidian-Prochloron symbiosis: the role of larval photoadaptations in midday larval release and settlement. Biol Bull (Woods Hole) 165:221-240

Olson RR, McPherson R (1987) Potential vs. realized larval dispersal: fish predation on larvae of the ascidian Lissoclinum patella (Gottschaldt). J Exp Mar Biol Ecol 110: 245-256

O'Riordan RM, Myers AA, McGrath D, Delany J, Power AM (1999) The sizes at settlement in natural populations of the cyprids of Chthamalus montagui and C. stellatus. J Mar Biol Assoc UK 79:365-366

Paula J (1989) Rhythms of larval release of decapod crustaceans in the Mira estuary, Portugal. Mar Biol 100:309-312

Paula J (1993) Ecologia da fase larvar e recrutamento de crustáceos decápodes no estuario do rio Mira. PhD thesis, Universidade de Lisboa, Lisbon

Pearse JS (1975) Lunar reproductive rhythms in sea urchins. A review. J Interdiscip Cycle Res 6:47-52

Power AM, Myers AA, O'Riordan RM, McGrath D, Delany J (2001) An investigation into rock surface wetness as a

Editorial responsibility: Otto Kinne (Editor-in-Chief), Oldendorf/Luhe, Germany parameter contributing to the distribution of the intertidal barnacles Chthamalus stellatus and Chthamalus montagui. Estuar Coast Shelf Sci 52:349-356

Pyefinch KA (1948) Methods of identification of the larvae of Balanus balanoides (L.), B. crenatus Bruguière and Verruca stroemia O.F. Müller. J Mar Biol Assoc UK 28: 451-463

Queiroga H, Costlow JD, Moreira MH (1994) Larval abundance patterns of Carcinus maenas (Decapoda, Brachyura) in Canal de Mira (Ria de Aveiro, Portugal). Mar Ecol Prog Ser 111:63-72

Saigusa M (1982) Larval release rhythms coinciding with solar day and tidal cycles in the terrestrial crab Sesarmaharmony with semilunar timing and its adaptive significance. Biol Bull (Woods Hole) 160:311-321

Saigusa M, Kawagoye O (1997) Circatidal rhythm of an intertidal crab, Hemigrapsus sanguineus: synchrony with unequal tide height and involvement of a light-response mechanism. Mar Biol 129:87-96

Sokal RR, Rohlf FJ (1995) Biometry, 3rd edn. Freeman, New York

Southward AJ (1976) On the taxonomic status and distribution of Chthamalus stellatus (Cirripedia) in the North-East Atlantic region: with a key to the common intertidal barnacles of Britain. J Mar Biol Assoc UK 56:1007-1028

Starr M, Himmelman JH, Therriault JC (1991) Coupling of nauplii release in barnacles with phytoplankton blooms: a parallel strategy to that of spawning in urchins and mussels. J Plankton Res 13:561-571

Walker (1992) Cirripedia. In: Harrison FW, Humes AG (eds) Microscopic anatomy of invertebrates, Vol 9. Crustacea. Wiley-Liss, New York, p 249-312

Submitted: October 8, 2004; Accepted: March 31, 2005

Proofs received from author(s): July 29, 2005 